\title{
投稿論文
}

甲状腺眼症のパルス治療前後でのゴールドマン視野計を用いた 注視野による定量化の検討

藤井美奈子 ${ }^{1)}$ ・ 小谷 聖子 ${ }^{1)}$ - 岡本 邦代 ${ }^{1)} \cdot$ 遠藤 弘毅 ${ }^{1}$ ・ 藤田 祐美 $^{1)} \cdot$ 佐藤 由果 ${ }^{1)} \cdot$ 西田詠美子 ${ }^{1)} \cdot$ 鈴木 $\quad$ 康夫 ${ }^{2)}$

1) 手稲渓仁会病院眼科

2) 手稲渓仁会病院眼窩・神経眼科センター

\section{Quantitative Assessment of the Binocular Single Vision Field Using the Goldmann Perimeter Before and After Steroid Pulse Therapy in Acute Thyroid-Associated Ophthalmopathy}

\author{
Minako Fujii ${ }^{11}$, Masako Kotani ${ }^{1}$, Kuniyo Okamoto ${ }^{1)}$, Hiroaki Endo ${ }^{11}$, \\ Yumi Fujita ${ }^{1)}$, Yuka Sato ${ }^{1}$, Emiko Nishida ${ }^{1)}$, Yasuo Suzuki ${ }^{2)}$ \\ ${ }^{1)}$ Department of Ophthalmology, Teine Keijinkai Hospital \\ ${ }^{2)}$ Orbital Disease \& Neuro-Ophthalmology Center, Teine Keijinkai Hospital
}

要 約

【目的】甲状腺眼症のパルス治療前後で両眼注視野をゴールドマン視野計を用いて定量的に評価す ることの有用性を検討した。

【対象と方法】2008年 4 月から 2011 年 7 月までに手稲溪仁会病院眼窩・神経眼科センターで、ステ ロイドパルス治療を受けた甲状腺眼症患者 19 名を対象とした。

【結果】急性期甲状腺眼症のパルス治療前後での両眼注視野をゴールドマン視野計にて測し、両眼 注視野面積、正面視を含む水平と垂直の融像域を評価した。両眼注視野の平均面積（土標準偏差） は、ステロイドパルス治療前が $33.7 \pm 20.7 \mathrm{~cm}^{2} 、$ 治療後が $53.1 \pm 23.8 \mathrm{~cm}^{2}$ であり、有意に拡大した $(P<1 \% 、 \mathrm{t}-$ 検定 $)$ 。

治療後に注視野面積が拡大した症例の治療前面積は $20.0 \pm 20.7 \mathrm{~cm}^{2} \quad(\mathrm{n}=15)$ 、縮小した症例では $85.2 \pm 49.3 \mathrm{~cm}^{2}(\mathrm{n}=4)$ であり、治療前面積は、縮小した症例のほうが有意に広かった $(P<1 \%$ ～ $\mathrm{t}$ 検定)。水平融像域、垂直融像域は、正面視で複視がある症例を除く16例で検討した。水平融像域 は治療前の平均 $53.1^{\circ}$ が、治療後は $85.9^{\circ}$ へ有意に拡大し、垂直融像域の平均も治療前の $48.2^{\circ}$ から

別冊請求先（ T 006-8555）北海道札幌市手稲区前田 1条 12 丁目 1-40 手稲溪仁会病院眼科
Tel. $011(685) 3888$
Fax. 011 (685) 3817
E-mail : smilea-r@sea.plala.or.jp

Key words : 甲状腺眼症、両眼注視野、ゴールドマン視野計

thyroid-associated ophthalmopathy, binocular single visual field, the Goldmann perimeter 
治療後は $78.0^{\circ}$ へ有意に拡大した。（水平、垂直とも $\mathrm{P}<5 \% 、 \mathrm{t}$-検定）

【結論】ゴールドマン視野計による両眼注視野は、甲状腺眼症患者の両眼単一視の範囲や位置を定 量的に知ることができ、ステロイドパルス治療の効果を評価する際に有用な指標である。

\begin{abstract}
【Purpose】 To assess the usefulness of the quantification of the binocular single vision field using the Goldmann perimeter in patients with thyroid-associated ophthalmopathy (TAO).

【Subjects and Methods】 Subjects were 19 patients (8 males and 11 females; age range, 25-66 years, average, 48.1 years) with acute TAO treated by steroid pulse therapy at the Orbital Disease \& Neuro-Ophthalmology Center, Teine Keijinkai Hospital between April 2008 and July 2011. The binocular single vision field was measured using the Goldmann perimeter before and after the steroid pulse therapy. The area of the binocular single vision field and the horizontal and vertical convergence ranges that covered the primary position (gaze position with the head in a straight position) were assessed using a personalcomputer.

【Results】 The average areas of the binocular single vision field before and after the steroid pulse therapy were $33.7 \pm 20.7 \mathrm{~cm}^{2}$ and $53.1 \pm 23.8 \mathrm{~cm}^{2}$, respectively. A significant increase in the area after the therapy was observed $(P<1 \%$, Student's t-test). The average areas of the field before therapy were $20.0 \pm 20.7 \mathrm{~cm}^{2}$ in the patients with an increased area after therapy $(\mathrm{n}=15)$ and 85.2 $\pm 49.3 \mathrm{~cm}^{2}$ in the patients with a decreased area after therapy $(\mathrm{n}=4)$. The average area before therapy significantly increased in those with a decreased area after therapy $(P<1 \%$, Student's t-test). Excluding the patients with double vision at the gaze position with a straight head position, sixteen patients were evaluated for their horizontal and vertical convergence ranges. Before and after the steroid pulse therapy, the respective average horizontal convergence ranges were $53.1^{\circ}$ and $85.9^{\circ}$; and the average vertical convergence ranges were $48.2^{\circ}$ and $78.0^{\circ}$. Both the horizontal and vertical convergence ranges significantly increased after the therapy $(P<5 \%$, Student's t-test).
\end{abstract}

【Conclusion】 Measurement of the binocular single vision field using the Goldmann Perimeter can quantify the range and location of the binocular single vision in patients with acute TAO and thusis useful for assessing the effect of steroid pulse therapy.

\section{I . 緒言}

甲状腺眼症は眼瞼症状、眼球突出、眼球運動 障害、視神経障害などの多彩な症状を呈する が、中でも患者の日常生活のQuality of Vision （QOV）を左右する症状に外眼筋肥厚・線維化 に伴う伸展障害による複視がある ${ }^{1)}$ 。複視を避 けるために代償頭位をとったり、片眼つむりを 行ったりする症例も多く、実際の眼球運動障害 と複視の自覚とに乘離がみられる症例を経験す ることも多い。

甲状腺眼症の眼球運動障害は両眼性に生じる ことが多く、単眼での眼球運動制限の評価やへ スチャートの所見が自覚している複視の程度に
結びつかないことも多い。これまで自覚してい る複視を定量化する方法として、バゴリーニ線 条鏡を用いる方法 ${ }^{2)}$ 、複視の生じる眼位によっ てその程度を分類する方法 ${ }^{3)} 、 9$ 方向眼位での複 視の程度をスコア化する方法 ${ }^{4)}$ が報告されてい る。これに対し、ゴールドマン視野計を用いた 两眼注視野は種々の眼球運動障害の変化を定量 的に記録するために用いられる検査法である が、甲状腺眼症に生じた複視の治療効果の定量 的評価に用いた報告はみられない。今回我々は 两眼注視野 (两眼単一視野、融像視野も同義 ${ }^{5}$ ) をゴールドマン視野計を用いて測定し、定量的 評価法としての有用性を検討した。 


\section{II. 対象と方法}

甲状腺眼症の急性期を判断する方法として、 臨床的活動性スコア (Clinical Activity Score) 6)を用いた。対象症例は、全てClinical Activity Scoreが4点以上にてパルス治療の適応と診断 した症例である。今回2008年4月から2011年 7 月までに手稲渓仁会病院眼窩・神経眼科セン ターにおいて、急性期と診断され複視の自覚が ありステロイドパルス療法を行った急性期甲状 腺眼症患者 19 名を対象とした。男性が 8 例、女 性が 11 例であり、平均年齢は 48.1 歳（25歳〜 66歳）であった。

注視野はゴールドマン視野計にて $\mathrm{V}-4$ 視標 を用いて測定し、パルス治療前後でのゴールド マン視野記録用紙上での両眼注視野面積をコン ピューターを用いて計測した。また、正面視を
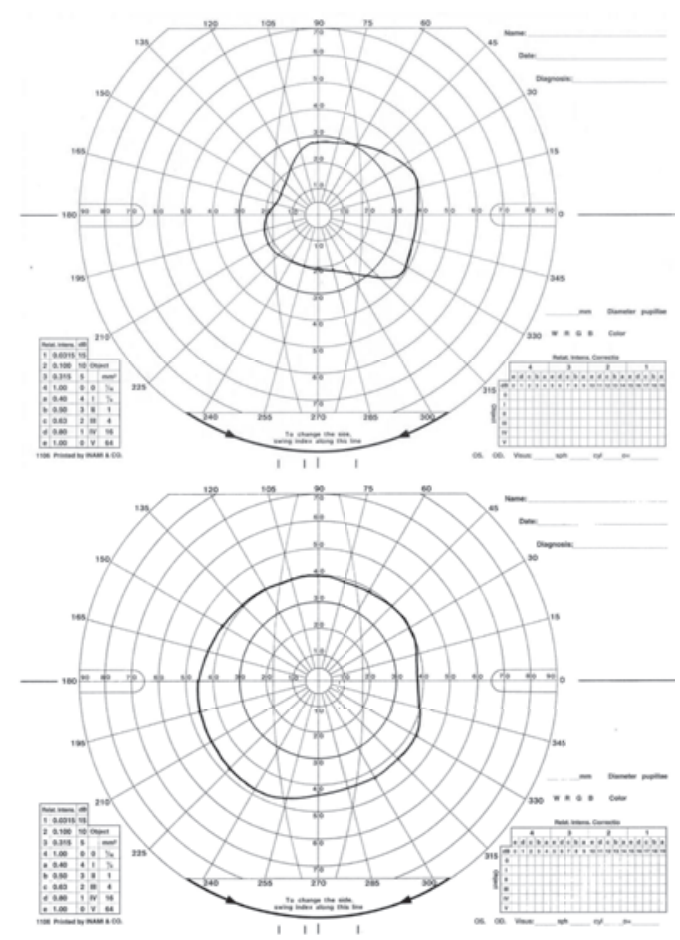

図 1 ステロイドパルス治療前後の両眼注視野（症 例8)

上がステロイドパルス治療前 $\left(23.7 \mathrm{~cm}^{2}\right) 、 下$ が治療後 $\left(56.5 \mathrm{~cm}^{2}\right)$ 治療により両眼注視野の 拡大が認められた。
含む水平、垂直方向の融像域も計測した。

ステロイドパルス治療は、メチルプレドニゾ ロン $1 \mathrm{~g}$ の点滴を 3 日間、それに引き続くプレ ドニゾロン $30 \mathrm{mg}$ の内服 4 日間の合計 7 日間を 1 クールとし、いずれの症例も 3 クール施行した。

\section{III. 結果}

治療前には両眼単一視野をもたなかった症例 6 名のうち 4 名が治療後に正面視での複視が消 失した。また正面視で複視があった 3 名も治療 後、全例で正面視での複視が消失した。ステロ イドパルス治療後、15例で両眼注視野面積は拡 大し、4例で縮小を認めた。面積拡大を認めた 症例 8 を図 1 に、面積縮小を認めた症例 16 を図 2 に示した。両眼注視野の平均面積（土標準偏 差）は、治療前が $33.7 \pm 20.7 \mathrm{~cm}^{2} 、$ 治療後が 53.1
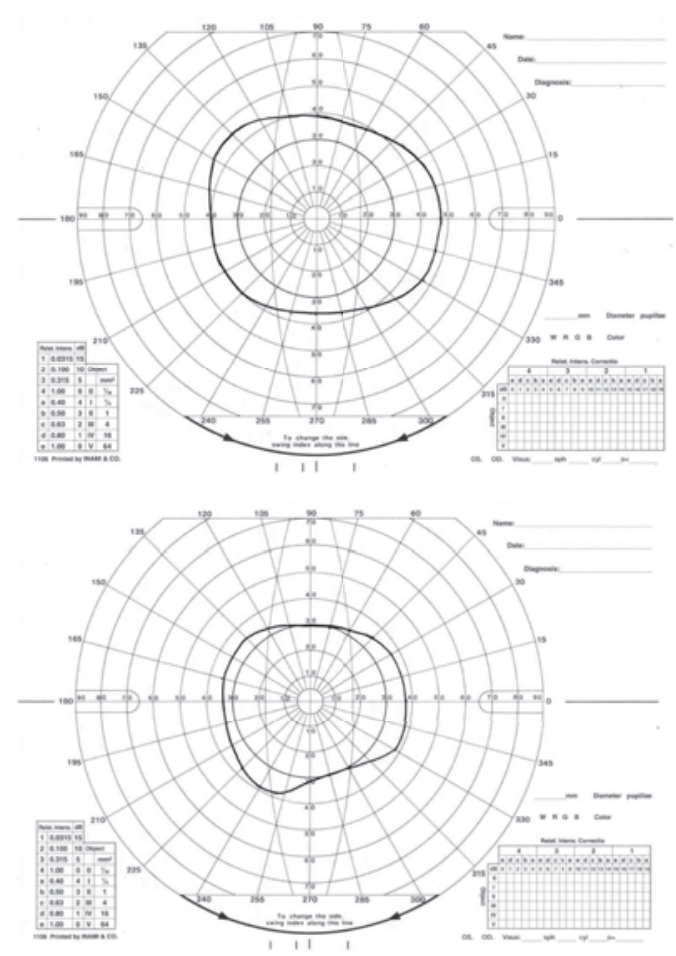

図2 ステロイドパルス治療前後の両眼注視野（症 例 16)

上がステロイドパルス治療前 $\left(54.2 \mathrm{~cm}^{2}\right) 、 下$ が治療後 $\left(35.6 \mathrm{~cm}^{2}\right)$ 治療後 両眼注視野の縮 小が認められた。 
$\pm 23.8 \mathrm{~cm}^{2}$ であり、統計学的に有意な拡大を示 した $(\mathrm{P}<1 \% 、 \mathrm{t}$-検定、図 3$)$ 。治療前平均面積 ( 標準偏差 $)$ は、面積が拡大した改善症例で は $20.0 \pm 20.7 \mathrm{~cm}^{2} （ \mathrm{n}=15 ）$ 、面積が縮小した悪化 症例では $85.2 \pm 49.3 \mathrm{~cm}^{2} （ \mathrm{n}=4 ）$ であり、治療前 両眼注視野は、縮小した 4 症例のほうが有意に 広かった（P<1\%、t-検定）が、その治療後平 均面積は $67.2 \pm 33.8 \mathrm{~cm}^{2}$ で、統計学的に有意な縮 小ではなかった（P=0.14、 $\mathrm{t}$-検定 $)$ 。

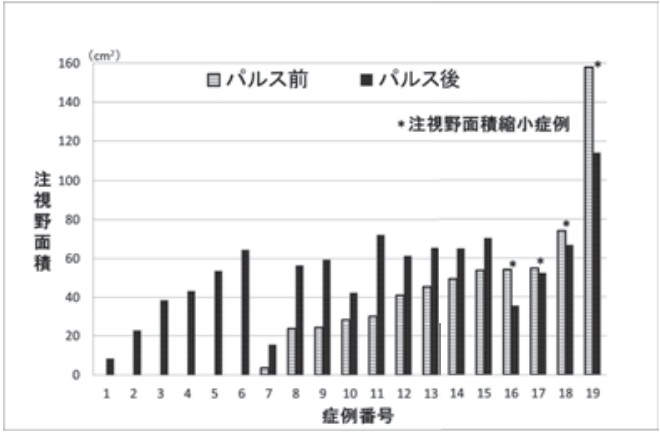

図3両眼注視野面積の治療前後の比較

症例は治療前の両眼注視野面積が小さいも のから並べてある。症例 1 から 6 は治療前に両 眼注視野を認めなかった。

治療前の両眼注視野面積が広かった 4 症例 （症例 16、17、18、19）で治療後に両眼注視野 面積の縮小を認めた。

水平融像域、垂直融像域は、正面視で複視が ある症例は除外し16例で検討した。水平融像域 は治療前の平均が $53.1^{\circ}$ であったが、治療後は $85.9^{\circ}$ へと有意に拡大していた $(\mathrm{P}<5 \%$ 、 $\mathrm{t}$ 一検 定)。治療後に水平融像域の悪化を認めた症例 は4例あったが、これらは治療前水平融像域が 広い上位 4 例であり、その平均融像域は $111.3^{\circ}$ であった（図4）。治療前の垂直融像域の平均は $48.2^{\circ}$ 、治療後の平均は $78.0^{\circ}$ であり、水平融像 域と同様に有意な拡大が見られた $(\mathrm{P}<5 \%$ 、 一検定)。治療後に垂直融像域の悪化を認めた 症例は治療前垂直融像域が 19 例で 1 番目と 4 番 目に広い 2 例であり、その平均治療前垂直融像 域は $101.5^{\circ}$ であった（図5）。

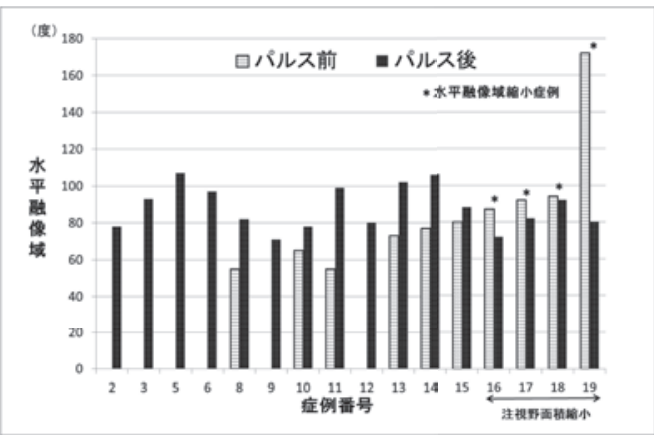

図4 水平融像域の治療前後の比較

治療後に融像域が縮小した 4 例（*) は、治 療後に両眼注視野面積が縮小した症例に一致 していた。治療前の正面視時に複視のあった 症例 $1 、 4 、 7$ は除いてある。

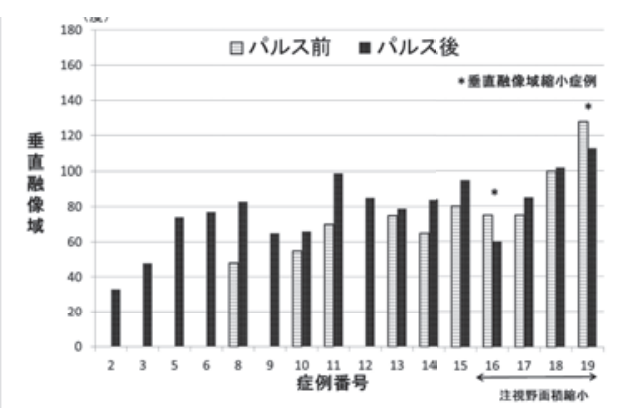

図5垂直融像域の治療前後の比較

治療後に融像域が縮小した 2 例（*)は、い ずれも治療後に両眼注視野面積の縮小を認め た症例であった。図 4 と同様に症例 $1 、 4 、 7$ は 除いてある。

\section{IV. 考案}

今回我々はゴールドマン視野計を用いて両眼 注視野を面積として定量化し、急性期甲状腺眼 症の複視に対するステロイドパルス治療の治療 効果を統計学的に評価することを試みた。複視 の状態を定量的に把握するためには、注視野面 積を正確に測定することが必要不可欠である。 ゴールドマン視野計には頭部を固定することで 代償頭位を矯正し、正面視で検査距離を一定に して、同じ条件下で簡便に測定することができ るという利点がある反面、検査中に観察筒から 眼球運動の状態や固視の様子を見ることができ ないという欠点もある。そのため、事前に検査 
の内容、目的の十分な説明を行うことが大切で ある。

ステロイドパルス治療により、複視のみでな く、眼瞼や結膜症状、眼球運動痛なども改善 することから、治療後の自覚症状は概ね良好で あった。ステロイドパルス治療によって、両眼 注視野が縮小した症例は、改善した症例より治 療前の両眼注視野が有意に広かったことから、 急性期甲状腺眼症に対するステロイドパルス治 療は、治療前両眼注視野が狭い症例では改善す る可能性が高いが、広い症例では逆に悪化を生 じる可能性もあることがわかった。また、両眼 注視野の水平融像域が悪化した 4 例と、垂直融 像域の悪化した 2 例全てが両眼注視野面積の悪 化を認めた症例であった。しかし、治療により 単眼でのひき運動に悪化を生じた症例はなく、 左右眼への治療効果の差が眼球運動制限の左右 差を拡大し、両眼注視野面積を縮小させた可能 性が示唆された。

注視野面積が縮小した 4 症例に、日常での複 視の悪化を訴えた例はなかった。これらの症例 は治療前の両眼注視野が広く、面積縮小後も周 辺視での複視をわずかな代償頭位で補正するこ とができたため、複視の悪化を感じなかったの であろうと思われた。

甲状腺眼症は後天性の眼球運動障害であり、 ほとんどの症例が良好な両眼視を有している。 ステロイドパルス治療は、甲状腺眼症で生じて いる眼球運動制限を改善するがその効果は左右 眼で独立している。単眼での眼球運動（ひき運 動）の改善が、眼球運動制限の左右差の縮小を もたらした場合に両眼単一視野の拡大が得られ るのだが、このことは融像域にもあてはまり、 16 例中 14 例で注視野面積の拡大・縮小は、水 平、および垂直融像域の拡大・縮小に一致して いた。しかし、2症例（症例17、18）では、注
視野面積が縮小し、水平融像域も縮小したが垂 直融像域は逆に拡大していた。この原因は、ス テロイドパルス治療の眼球運動改善効果が眼球 運動の方向で異なっていたためと考えられる。

今回の検討によって、急性期甲状腺眼症にス テロイドパルス治療が両眼注視野面積・水平・ 垂直融像域を定量的に測定することで統計学的 に有意な拡大として示すことができた。

このことは、複視をもつ甲状腺眼症患者を評 価する際に、ゴールドマン視野計による両眼注 視野測定が有用であること、両眼注視野面積が 有用な指標であることを示唆していると思われ た。

\section{参考文献}

1 ) 鈴木康夫: 甲状腺眼症の病態と治療. 日本の 眼科 78: 163-164, 2007

2 ) 新井紀子, 深井小久子, 早川友恵, 木村 久, 田渕昭雄: 甲状腺眼症の眼球運動障害に対す る視能訓練. 日本弱視斜視学会雑誌第 20 卷: 161-165, 1993

3 ) 赤塚俊文: 甲状腺眼症の眼位管理. 眼臨 97 : 217-221, 2003

4 ）柴田拓也, 濱田瑞恵, 田口亜希子, 石井祐子, 若倉雅登, 井上治郎: 甲状腺眼症の治療前後 における定量的眼位と複視の評価.日視会誌 第 36 巻: 113-117, 2007

5 ) 平井敏江: 丸尾敏夫, 久保田伸枝, 深井小久子 (編) : 視能学増補版 330-331、文光堂 東京 2005

6 ) Mourits MP, Koornneef L, Wiersinga WMet. al: Clinical criteria for the assessment of disease activity in Graves' ophthalmopathy. A novel approach. Br J Opthalmol. 73: 639644, 1989 